\title{
Short- And Long-Term Wealth Gains From UK Takeovers: The Case Of The Financial Industry
}

Sabri Boubaker, Champagne School of Management, Groupe ESC Troyes, \& IRG, Université Paris Est, Créteil, France Taher Hamza, Tunisia State University at Sousse \& Université d'Orléans, France

\begin{abstract}
The present study analyzes the short- and long-term performance of UK financial acquiring firms by examining a sample of 40 takeovers over the period 1996-2007. In particular, it investigates i) the short- and long-term stock return performance of these acquiring firms and ii) the relation between their short-term abnormal return around the announcement date of takeovers and their long-term performance. The event study methodology shows that bidders experience significant short-term wealth destruction. In contrast, both the buy-and-hold abnormal returns and bidder's portfolio return approaches indicate positive and significant wealth effects over the long run. Business cycle analysis shows that acquirers obtain significantly higher returns during downward financial market cycles. Furthermore, the results show that the market reaction to the bid announcement better predicts bidders' long-term performance in the case of positive short-term abnormal returns.
\end{abstract}

Keywords: Takeovers; UK Financial Institutions; Abnormal Returns; Bidder's Portfolio Return; Business Cycle Analysis; Shareholders' Value

\section{INTRODUCTION}

O

uccessive waves of corporate acquisitions have prompted researchers to focus on bidders' strategic motivations. ${ }^{1}$ Empirical results regarding bidder wealth effects from acquisitions are very controversial and lend support to many theoretical arguments. Manne (1965) is among the first to have examined the market's disciplinary role of corporate control in improving operational efficiency and corporate performance. Jensen (1986) argues that managers of firms with large free cash flows are more likely to undertake value-destroying acquisitions. Shleifer and Vishny (1989) contend that entrenched managers are willing to make acquisitions and to overpay for their targets to avoid losing their jobs. In contrast, Roll (1986) argues that product and labor markets, as well as the market for corporate control, are efficient and support the hubris hypothesis, illustrating the importance of behavioral biases as a theoretical framework for understanding managerial decisions. Nonetheless, the search of operating, financial, and organizational synergies remains the most important argument advanced by bidder managers when justifying acquisitions. Another stream of research supports the overvaluation or market timing hypothesis in the context of temporarily inefficient financial markets. In this vein, Shleifer and Vishny (2003) argue that high stock prices during upward financial market cycles provide acquiring firms with incentives to implement acquisition strategies. The managers of these acquiring firms can also recourse to earnings manipulation to achieve high stock valuation, hence reducing acquisition costs. Several studies confirm bidder equity overvaluation and show that managers of acquiring firms manipulate earnings prior to the acquisition announcement (e.g., Erickson \& Wang, 1999). For instance, they may decide to inflate earnings by using discretionary accruals to reduce acquisition costs.

\footnotetext{
${ }^{1}$ In this paper, we use the terms bidder and acquiring firm interchangeably.
} 
The present study investigates the short- and long-term performance of corporate takeovers involving UK financial institutions over the period 1996-2007. Moreover, it investigates the link between bidder short- and longterm performance. Does the market reaction around the acquisition announcement predict bidder long-term performance? This research question has received little attention in the literature. Event study analysis shows that bidders experience significant short-term wealth destruction. In contrast, both the buy-and-hold abnormal return (BHAR) and bidders' portfolio return approaches indicate a positive and significant wealth effect over the long run. Furthermore, business cycle analysis shows that acquirers obtain significantly higher returns during a downward financial market cycle. Finally, the market reaction to the bid announcement better predicts bidders' long-term performance in the case of positive short-term performance.

The remainder of this paper is organized as follows. Section 2 reviews the literature on the short- and longterm stock return performance of the acquiring firms. Section 3 presents the sample, methodology, and empirical results. The last section concludes the paper.

\section{LITERATURE REVIEW}

We study the bidder wealth effects of takeovers in the UK financial sector before the crisis that began in 2007. During the past two decades, we have witnessed significant changes in the financial system through an important concentration process. This process has led to an increase in the intensity of competition that has undermined the stability of the sector and exacerbated the risk-taking behavior of financial institutions. In this context, we analyze the effects of takeovers on shareholder value.

Several studies that focus on the short-term wealth effects of takeovers in the financial sector report negative short-term performance for the bidders (Becher, 2000; Amihud et al., 2002; Bessler \& Murtagh, 2002; Williams \& Liao, 2008). They reject the synergetic hypothesis and support the argument that managers overestimate expected synergies of corporate acquisition (i.e., the managerial hubris hypothesis). Franks et al. (1991) examine the short-term impact of mergers and acquisitions (M\&As) of US financial institutions and find significant value destruction for the bidder. Amihud et al. (2002) show that acquiring banks exhibit negative short-term returns. The results are in line with the argument that acquiring banks overpay for targets, which leads to a value destruction strategy. The studies of Becher (2000) and Bessler and Murtagh (2002), among others, confirm these results. They consistently show that US bank mergers do not create value, irrespective of whether they are focused or diversified. Similarly, Williams and Liao (2008) indicate that target abnormal returns are mostly positive and significant but are offset by negative abnormal returns for acquiring banks. In contrast, Beitel and Schiereck (2004) find significant positive abnormal returns in Canada. Similarly, Cybo-Ottone and Murgia (2000) indicate that when the short-term gains of European acquiring banks are compared to the market index, the results show a significant and positive market reaction in the shorter event windows. The results obtained using the bank sector index indicate a negative effect and are not consistent with those obtained using the market index. The authors support the argument of a contagious effect of the acquisition announcements. Indeed, the positive market reaction increases the stocks of the other banks, which anticipates market concentration and greater bank profits. In addition, financial analysts expect further acquisitions, which causes higher sector index level, reducing excess returns. Lastly, Beitel et al. (2004) and Campa and Hernando (2006) find no significant short-term wealth effects for acquiring banks.

The literature examining the long-term performance of acquiring firms seems to yield less controversial results. Studies on the US, UK, Canadian, and European markets (e.g., Agrawal et al., 1992; Cybo-Ottone \& Murgia, 2000; Mitchell \& Stafford, 2000; Chatterjee \& Aw, 2004; Andre et al., 2004) show that these firms experience negative long-term abnormal returns after takeovers. These studies support arguments in the literature that managerial behavior, synergy overestimation, and acquisition timing are important explanations of takeover decisions. However, these results may be an artifact of the methodologies used to measure long-term performance. Studying financial firms, Houston et al. (2001) indicate that bank merger effects improved over time but a high number of them did not experience significant revenue enhancements. Behr and Heid (2011) show a neutral effect of bank takeovers on profitability and cost efficiency. They conclude that the literature do not provide clear-cut findings regarding the long-term profitability of bank M\&A's due to severe methodological problems. A contrasting view is that of Akhavein et al. (1997), who show that the mega-mergers of the 1980s exhibited significant profit efficiency gains. Similarly, Berger and Mester (2003) find that US banks engaged in M\&As during 1991-1997 
substantially improved profit productivity but not cost productivity. Cuesta and Orea (2002) show that M\&As increased technical efficiency in Spain. Koetter (2008) indicates that only half of German bank mergers perform well.

Studies examining the relation between bidder's short- and long-term performance are rare. The purpose of studying such a relation is to see whether the market reaction around the acquisition announcement predicts the bidder's long-term performance. If this relation exists, one would expect that the short-term abnormal return around the announcement date can signal the bidder's long-term expected synergies. Thus, investors are more likely to buy the stocks of acquiring firms that exhibit higher short-term returns around the bid announcement. According to Agrawal et al. (1992) two scenarios are of interest. On the one hand, the market price adjustment to the acquisition event is fast and the subsequent underperformance is due to factors that are a priori not identifiable. On the other hand, the market price adjustment to the acquisition event is slow and, thus, the bidder's long-term performance is not perfectly captured by the short-term reaction.

Empirical research on this issue documents mixed results. For instance, Agrawal et al. (1992) find a negative relation between the short-term market reaction to takeover announcements and bidder long-term performance. Campa and Hernando (2006) show that the short-term gains around announcements are not good predictors of bidder long-term performance. Conversely, Olson and Pagano (2005) emphasize that the short-term market reaction to M\&A announcements reveals investor expectations regarding the deal's prospects. These expectations may not be achieved due to the information asymmetries between managers and shareholders. Thus, the success or failure of bank M\&As should not be appreciated solely on market reaction effects but, rather, on the long-term post-acquisition performance of the acquirer's stock. According to Pécherot-Petitt (2000), the probability that the short-term market reaction to the acquisition event anticipates the long-term performance of the bidders is 70\%. In this regard, Malatesta and Thompson (1985) consider the economic impact of an event as the present value of the cash flows that it generates. In efficient capital markets, abnormal stock returns following the announcement of an acquisition should reflect the present value of expected long-term synergies when the market is able to anticipate post-acquisition performance.

\section{EMPIRICAL ANALYSIS}

Our research focuses on the performance of UK financial acquiring firms. The financial industry is characterized by specialization strategies and high levels of profitability since the mid-1990s. Moreover, empirical studies provide evidence of value destruction of the takeovers of financial institutions over the long term (e.g., Chatterjee \& Aw, 2004). The following presents our sample, methodology, and results.

\subsection{Sample Selection}

Our initial sample includes all 188 takeovers that were initiated by UK financial institutions listed on the London Stock Exchange and completed between 1996 and 2007. Following previous studies (e.g., Andre et al., 2004), we omit takeovers with a deal value lower than $\$ 10$ million, a threshold chosen to ensure a significant market impact of the transactions. In addition, only transactions with available historical stock prices and financial data were selected. The final sample includes 40 UK financial takeovers between May 1996 and March 2007. Financial data were collected from the Thomson One Banker database. Market data were obtained from the Datastream database.

\subsection{Methodology and Results}

We use an event study methodology to estimate bidders' short-term performance. This approach measures the stock market reaction to the offer announcement. To evaluate bidder's long-term performance, we use two different methodologies. First, we calculate the BHAR for bidder shareholders and compare them with the long-term returns of control firms. Second, as a robustness test, we estimate the value index of a portfolio composed of acquirers' stocks. The latter is compared over the same period to a benchmark market portfolio. 


\subsubsection{Bidder Short-Term Performance: An Event Study Analysis}

We use an event study methodology to evaluate abnormal returns. This methodology implicitly supposes that the event is exogenous to the modification of firm market value. Brown and Warner (1985) indicate that the market model, despite its simplicity, is a standard for evaluating abnormal returns around event announcements. In this study, we calculate abnormal returns using the market model at the very first announcement of the takeover. An abnormal return $\left(A R_{i, t}\right)$ is the difference between the observed return at date $\mathrm{t}$ and the expected return as predicted by the market model:

$\mathrm{AR}_{\mathrm{i}, \mathrm{t}}=\mathrm{R}_{\mathrm{i}, \mathrm{t}}-\mathrm{R}_{\mathrm{i}, \mathrm{t}(\text { market model })}$

$\mathrm{AR}_{\mathrm{i}, \mathrm{t}}=\mathrm{R}_{\mathrm{i}, \mathrm{t}} \mathrm{E}\left(\mathrm{R}_{\mathrm{i}, \mathrm{t}}\right)=\mathrm{R}_{\mathrm{i}, \mathrm{t}}-\left(\tilde{\alpha}_{\mathrm{i}}^{\mathrm{b}}+\tilde{\beta}_{\mathrm{i}}^{\mathrm{b}} * \mathrm{R}_{\mathrm{m}, \mathrm{t}}\right)$

where:

$\mathrm{AR}_{\mathrm{i} . \mathrm{t}}$ : Abnormal return.

$\mathrm{R}_{\mathrm{i}, \mathrm{t}}:$ Observed return.

$\mathrm{E}\left(\mathrm{R}_{\mathrm{i}, \mathrm{t}}\right)$ : Expected return in the situation of absence of event.

$\left(\tilde{\alpha}_{i}{ }_{i}^{b}, \tilde{\beta}_{i}^{b}\right)$ : Estimated coefficients obtained by OLS over the pre-event period. We consider the estimation window [$180,-21]$ relative to the event date.

$\mathrm{R}_{, \mathrm{t}}$ : Market return observed at date $\mathrm{t}$.

The cumulative abnormal return (CAR) of the bidder's firm is computed as follows:

$\mathrm{CAR}_{\mathrm{i},[\mathrm{t}, \mathrm{t} 2]}=\sum_{\mathrm{t}=\mathrm{t} 1}^{\mathrm{t} 2} \mathrm{AR}_{\mathrm{i}, \mathrm{t}}$, with $\mathrm{t}_{1} \leq \mathrm{t} \leq \mathrm{t}_{2}$

The average abnormal return for the whole sample at date $\mathrm{t}$ is computed using the following formula:

$\operatorname{AAR}_{t}=\frac{\sum_{i=1}^{N} \mathrm{AR}_{\mathrm{i}, \mathrm{t}}}{\mathrm{N}}$

where:

$\mathrm{N}$ is the number of bidding firms of the study sample.

The cumulative average abnormal returns for the whole sample on event window is:

$\operatorname{CAAR}_{\mathrm{i}}\left(\tau_{1}, \tau_{2}\right)=\frac{\sum_{\mathrm{t}=\tau 1}^{\tau 2} \operatorname{CAR}_{\mathrm{i}}\left(\tau_{1}, \tau_{2}\right)}{\mathrm{N}}$

Binder (1998) shows that the market model approach is appropriate to gauge short-term abnormal returns around an event date. During an acquisition transaction, the event date often used by previous empirical works is that of the event official announcement, which seems to be most relevant. In this study, the event window chosen is 40 trading days, $[-20,+20]$, and the estimation window is about 160 trading days. ${ }^{2}$ According to the investor's rationality hypothesis, a price increase (decrease) is synonymous of an approval (disapproval) acquisition decision

\footnotetext{
${ }^{2}$ The event window $[-20,+20]$ is divided into three event windows: market anticipation (pre-event $\left.[-20,-1]\right)$, event day market reaction (event $[0,0])$, and market price adjustment (post-announcement $[+5,+20])$.
} 
by the market (Binder, 1998). Table 1 presents the cumulative average abnormal returns CAARs of the acquirer over different event windows.

Table 1: Cumulative Average Abnormal Return (CAAR) of the Acquirer over Different Event Windows

\begin{tabular}{l|c|c}
\hline & Event Windows & CAAR/AAR(\%) \\
\hline Market reaction centered on the event day & {$[-20,+20]$} & $-1.875^{* * *}$ \\
\hline \multirow{2}{*}{ Market anticipation } & {$[-20,-6]$} & $-0.093 \%$ \\
\hline Event day market reaction (AAR) & {$[-5,-1]$} & $0.129 \% * *$ \\
\hline Market reaction centered on the event day & {$[0,0]$} & $-0.616 \%$ \\
\hline Post-announcement market reaction & {$[-5,+5]$} & $-0.935 \% * * *$ \\
\hline
\end{tabular}

$*, * *, * * *$ denotes significance at the $10 \%, 5 \%$, and $1 \%$ level.

Table 1 shows that the announcement of takeover bids generate negative and significant CAARs. Over the event window $[-20,-6]$, the CAAR is statistically insignificant and amounts to $-0.093 \%$, indicating that the bid was not anticipated by the investors over this window. A few trading days before the event (event window $[-5,-1]$ ), the CAAR is $0.129 \%$ and statistically significant at the $5 \%$ level, which indicates a market pre-bid reaction. On the event day, we observe a negative but statistically non-significant average abnormal return of $-0.616 \%$. This suggests that the market reacts slightly at the offer announcement. Over the 10-day window centered on the event day $[-5,+5]$, the CAAR is negative and statistically significant at the $1 \%$ level and amounts to $-0.935 \%$. The stock market reaction indicates a price adjustment based on market information flows after the announcement of the event. In the period $[+6,+20]$, the CAAR is also negative and statistically significant at the $1 \%$ level, at $-0.847 \%$. These results indicate a wealth loss for the shareholders of the acquiring firms around the announcements of takeovers, suggesting that takeovers by financial institutions are significantly value destructive. These findings are in line with those of previous studies (e.g., Franks et al., 1991; Becher, 2000; Cybo-Ottone \& Murgia, 2000). This underperformance may be justified by managerial hubris, leading acquirers to overestimate the takeover gains (Roll, 1986).

In the following, we divide our sample between acquisitions occurring during high-valuation markets and those occurring during low-valuation markets over the study period. ${ }^{3}$ Rhoder-Kropf and Viswanathan (2004) argue that acquisitions undertaken during high-valuation markets generate high performance and vice versa. Similarly, Bouwman et al. (2007) show that in the short-term, abnormal returns from announcements of acquisitions occurring during booming markets are significantly better than those obtained during depressed markets.

Table 2: Cumulative Average Abnormal Returns Based on Market Cycle on the Window [-20,+20]

\begin{tabular}{lcccc}
\hline \multicolumn{1}{c}{ Market Valuation Cycle } & CAAR [-20,+20] & T-Student & $\begin{array}{c}\text { Comparison average tests } \\
\text { (t-statistic) }\end{array}$ & T-Wilcoxon \\
\hline High valuation markets $(\mathrm{N}=32)$ & $-3.45 \%$ & -0.41 & \multirow{2}{*}{1.19} & 0.45 \\
Low valuation market $(\mathrm{N}=8)$ & $4.24 \%$ & $1.87 *$ & & \\
\hline
\end{tabular}

$*, * *, * *$ denotes significance at the $10 \%, 5 \%$, and $1 \%$ level.

The empirical results by market valuation cycle show that acquisitions during low-valuation markets (CAAR of $4.24 \%$ ) outperform those during high-valuation markets (CAAR of $-3.45 \%$ ) (see Table 2). This result contrasts with those previously obtained by Bouwman et al. (2007), who suggest that the positive short-term abnormal return is due to investor optimism during a booming market.

\subsubsection{Bidder Long-Term Performance: A BHAR Analysis}

There are two basic approaches for detecting long-term performance, namely, CAAR and BHAR. According to Barber and Lyon (1997), the long-term CAAR for firm i adjusted for normal performance over T months post-event is calculated according the following formulas:

$\mathrm{CAAR}_{\mathrm{t}_{1}, \mathrm{t}_{2}}=\sum_{\mathrm{t} 1}^{\mathrm{t} 2} \overline{\mathrm{AR}_{\mathrm{t}}}$

${ }^{3}$ The decomposition of the sample into two subsets is based on the trend chart analysis of the UK market index (FTSE 100). 


$$
\mathrm{AR}_{\mathrm{it}}=\mathrm{R}_{\mathrm{it}}-\mathrm{E}\left(\mathrm{R}_{\mathrm{i}} \text {, benchmark }\right)
$$

where:

$\mathrm{R}_{\mathrm{i}}$ is the real monthly return of $i$ at $t$.

$\mathrm{E}\left(\mathrm{R}_{(\mathrm{i}, \text { benchmark })}\right)$ : Expected or theoretical monthly return of $\mathrm{i}$ at $\mathrm{t}$.

In reference to the BHAR method, abnormal returns are based on compound interest at floating rates. Mitchell and Stafford (2000) describe the BHAR as "the average multiyear return from a strategy of investing in all firms that complete an event and selling at the end of a pre-specified holding period versus a comparable strategy using otherwise similar nonevent firms." It is therefore the difference between the return of a firm announcing an event $\mathrm{i}$ and that of a benchmark during the same period (Barber \& Lyon, 1997).

$$
\mathrm{BHAR}_{\mathrm{i}, \mathrm{T}}=\left[\prod_{\mathrm{T}=1}^{\mathrm{t}}\left(1+\mathrm{R}_{\mathrm{i}, \mathrm{T}}\right)-\prod_{\mathrm{T}=1}^{\mathrm{t}}\left(1+\mathrm{R}_{\mathrm{bench}, \mathrm{T}}\right)-1\right]
$$

Barber and Lyon (1997) underline that the CAARs in long-term windows are subject to three types of biases and are biased estimators compared to the BHAR approach. ${ }^{4}$ Moreover, the advantage of the BHAR lies in its ability to take into account the experience of the investor through the compounding of returns (Barber \& Lyon, 1997), which makes the method more suitable to examine long-term financial performance following the announcement of a given event (See also Pécherot-Petitt, 2000). Barber and Lyon (1997) introduce the control firm method to evaluate CAARs in long-term windows to eliminate survivor bias, rebalancing bias, and skewness bias. To this end, Dimson and Marsh (1986) highlight the importance of adjusting by size in event studies and consider models of adjustment to be the most appropriate predictors of abnormal returns, since the behavior of firms of similar size is expected to be homogeneous. Loughran and Ritter (1995) incorporate an adjustment both in terms of size and for industry to individualize the effect of a takeover operation and stress that such approach provides more meaningful results. Thus, following the recommendations of Barber and Lyon (1997), we construct pairs by matching the size and type of financial activity to identify financial institutions that do not initiate a takeover during the long-term post-announcement period. These procedures provide the results shown in Table 3 below.

Table 3: Buy and Hold Abnormal Returns (BHAR) on Post-M\&A Event Windows

\begin{tabular}{lcccc}
\hline & $\mathbf{N}$ & $\mathbf{B H A R}$ & BHAR & BHAR \\
& & {$[\mathbf{1 , 1 2 m}]$} & {$[\mathbf{1 , 2 4 m}]$} & {$[\mathbf{1 , 3 6 m ]}$} \\
\hline BHAR & 40 & $3.266 \%$ & $10 ., 48 \%$ & $14.19 \%$ \\
t-statistic & & 0.542 & 1.209 & 1.052 \\
Adjusted t-statistic & & 0.466 & 1.231 & 1.033 \\
\hline
\end{tabular}

$*, * *, * * *$ denotes significance at the $10 \%, 5 \%$, and $1 \%$ level.

Table 3 shows that the BHARs are not statistically significant. However, after a comparison of these returns with those of control firms, we find UK financial acquirers outperform their control counterparts (unreported). ${ }^{5}$ On average, this excess performance is $9.312 \%$ three years after the bid announcement. Our results do not corroborate several UK studies, however, such as that of Chatterjee and Aw (2004). They also contrast with those of Andre et al. (2004) in the Canadian market. In the following, we split our sample based on stock market conditions. The results presented in Table 4 show positive long-term performance, regardless of the stock market's valuation cycle. This performance is higher in bear markets and reaches a peak of $49.96 \%$ over the window [1,36 months]. The comparison tests show that the average long-term performance achieved during bear markets is significantly higher than that obtained during bull markets, but only for the window [1,24 months].

\footnotetext{
${ }^{4}$ According to Barber and Lyon (1997), the CAAR method is related to the following biases: measurement bias, survivor or new listing bias, and skewness bias. As for the BHAR method, it is subject to survivor bias, rebalancing bias, and skewness bias.

5 The results are available from the authors upon request.
} 
Table 4: Buy and Hold Abnormal Returns (BHAR) and Valuation Market Cycle

\begin{tabular}{lccc}
\hline \multicolumn{1}{c}{ Valuation Market } & BHAR & BHAR & BHAR \\
& {$[\mathbf{1 , 1 2} \mathbf{m}]$} & {$[\mathbf{1 , 2 4 m}]$} & {$[\mathbf{1 , 3 6 m}]$} \\
\hline High valuation markets $(\mathrm{N}=32)$ & $2.003 \%$ & $2.685 \%$ & $5.254 \%$ \\
Low valuation markets $(\mathrm{N}=8)$ & $8.316 \%$ & $41.69 \%$ & $49.96 \%$ \\
Comparison average tests (t-Statistic) & 0.415 & $1.854 *$ & 1.338 \\
\hline
\end{tabular}

$*, * *, * * *$ denotes significance at the $10 \%, 5 \%$, and $1 \%$ level.

\subsubsection{Bidder Long-Term Performance: Portfolio Value Index Analysis}

To assess the bidder's long-term performance, we use a methodology based on the following steps. First, we calculate, for a given portfolio, a value index that measures the value of one monetary unit invested in the portfolio of acquiring firms over the whole study period (1996-2007). If a firm makes an acquisition at date $t$, it is introduced the month of the offer announcement to the bidder's portfolio initially formed. This portfolio is, in turn, recomposed each month over the study period. To evaluate the acquirer's portfolio performance (PA) and that of the benchmark (the London market index, FTSE100), we calculate the value index (VI), which capitalizes the equally weighted monthly returns of the portfolio as follows: ${ }^{6}$

$$
\begin{aligned}
& \mathrm{VI}(\mathrm{PA})_{\mathrm{m}}=\prod_{\mathrm{m}=1}^{\mathrm{T}} *\left[1+\mathrm{R}(\mathrm{PA})_{\mathrm{m}}\right] \\
& \mathrm{VI}(\mathrm{FTSE} 100)_{\mathrm{m}}=\prod_{\mathrm{m}=1}^{\mathrm{T}} *\left[1+\mathrm{R}(\mathrm{FTSE} 100)_{\mathrm{m}}\right]
\end{aligned}
$$

where:

PA: represents the portfolio of acquiring firms.

$\mathrm{R}(\mathrm{PA})_{\mathrm{m}}$ represents the acquirer's portfolio return in month $\mathrm{m}$.

FTSE100: is the market portfolio.

$\mathrm{m}$ : the number of monthly observations, $\mathrm{m}: 1,2 \ldots 131$ (11 years).

$\mathrm{R}(\mathrm{FTSE} 100)_{\mathrm{m}}$ represents the market portfolio return in month $\mathrm{m}$.

The mean comparison test indicates a significant difference between the two indices (Table 5). The portfolio of acquirers largely outperforms the market index (see Figure 1). These results recommend a portfolio investment strategy consisting of buying UK financial institutions that initiate takeovers over the study period. These findings corroborate the results obtained by the BHAR approach.

Overall, these results provide evidence of the positive and significant long-term performance of UK financial acquirers.

Table 5: Analysis of Different Portfolios' Returns

$\mathrm{VI}_{\mathrm{PA}}$ : Value Index of acquirer portfolio, $\mathrm{VI}_{\mathrm{FTSE100}}$ : Benchmark Value Index

\begin{tabular}{lcc}
\hline & VI(PA) & VI(FTSE100) \\
\hline $\begin{array}{l}\text { Portfolio average performance } \\
\text { t-statistic }\end{array}$ & 2.957 & 1.367 \\
$*, * *, * * *$ denotes significance at the $10 \%, 5 \%$, and 1\% level. & & $(13.920) * * *$ \\
\hline
\end{tabular}

\footnotetext{
${ }^{6}$ The difference in performance between the portfolio of acquirers and the benchmark is shown in Figure 1.
} 


\subsubsection{Relation between the Short-Term and Long-Term Performance of Acquiring Firms}

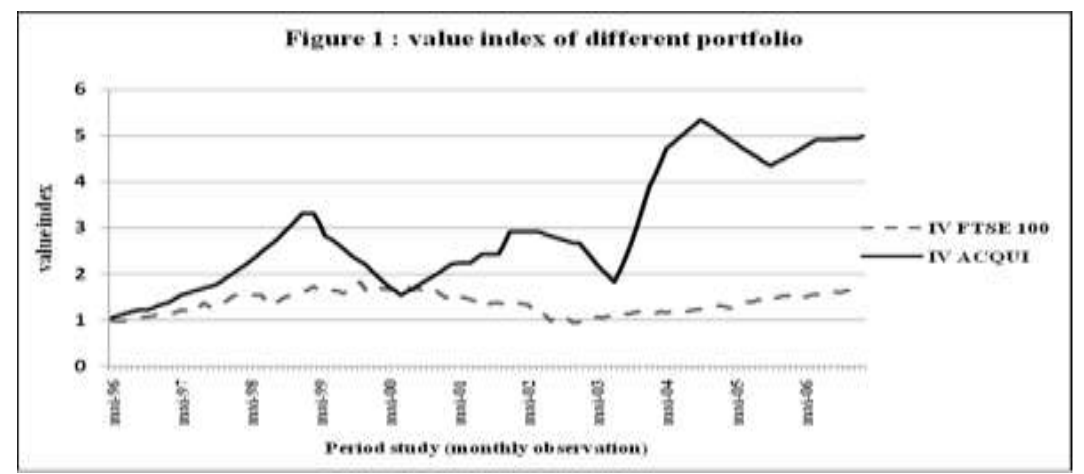

Market under-reaction to a bid announcement implies a positive and significant relation between bidder short-term and long-term performance (Agrawal et al., 1992). ${ }^{7}$ We split our sample into two groups, namely, prewinners and pre-losers (Pécherot-Petitt, 2000). In the short-term window, the pre-winners (pre-losers) are acquirers who exhibit a positive (negative) CAAR. To confirm the ability of the UK market to predict the sign of bidder longterm performance, we investigate which of the two groups, pre-winners or pre-losers, can maintain its long-term outperformance. Table 6 shows that the long-term CAAR of the pre-winners is positive and statistically significant $(10.43 \%)$ at the $1 \%$ level, while the pre-losers exhibit a negative and significant long-term CAAR $(5.12 \%)$. In other words, investors buy the stocks of acquiring firms that exhibit higher abnormal returns around the bid announcement. In addition, the mean comparison tests, both parametric and non-parametric, indicate a significant difference in performance between these two categories of acquirers. During the post-takeover announcement trading period, the UK market revises its previous expectations upward for both pre-winners and pre-losers. The market's ability to predict bidder long-term performance based on its short-term reaction is verified only for prewinners; however, it occurs in the opposite direction for pre-losers. The positive relation between bidder short- and long-term performance remains inconclusive, since the short-term market reaction better predicts pre-winner acquirer's long-term gains. Our results are in line with those of Pécherot-Petitt (2000), who shows that the French financial market fails to anticipate the extent of long-term wealth variation.

Table 6: Bidder Long-Term Performance of Short Term Pre-Winners vs. Pre-Losers

\begin{tabular}{lcc}
\hline \multicolumn{1}{c}{ Event Windows } & Winners & Losers \\
\hline Pre-acquisition CAAR [-20,+20] & Pre-Winners & Pre- Losers \\
\hline Mean & $7.60 \%$ & $-6.98 \%$ \\
Median & $4.88 \%$ & $-5.52 \%$ \\
Standard deviation & $8.31 \%$ & $6.13 \%$ \\
Z-stat & $3.77 * * *$ & $-5.34 * * *$ \\
Parametric test (T-statistic) & & Pre- Losers \\
Non parametric test (Test of Wilcoxon) & & $5.12 \%$ \\
\hline Post-acquisition BHAR [1,36 m] & Pre-Winners & $8.20 \%$ \\
\hline Mean & $10.43 \%$ & $2.31^{* * *}$ \\
Median & $21.41 \%$ & 1.065 \\
Standard deviation & $33.92 \%$ & 1.268 \\
Z-stat & & \\
Parametric test (t-statistic) & & 0.59 \\
Non parametric test (Test of Wilcoxon) & & 0.835 \\
\hline
\end{tabular}

$*, * *, * * *$ denotes significance at the $10 \%, 5 \%$, and $1 \%$ level.

\section{CONCLUSION}

The present research investigates financial bidders' wealth effects from UK takeovers. The UK financial sector has been characterized by specialization strategies and high levels of profitability since the mid-1990s.

\footnotetext{
${ }^{7}$ The paper provides an intertemporal analysis of financial analyst's reactions to good and bad news and evaluates the relation between over- and under-reaction to information and optimism bias.
} 
Previous empirical studies show the value destruction of financial acquirers following takeovers over the long-term (Chatterjee \& Aw, 2004).

We focus on the short-term and long-term performance of UK financial acquiring firms by examining a sample of 40 takeovers over the period 1996-2007. We also investigate the link between bidders' short- and longterm performance. The event study shows that financial bidders exhibit significantly negative CAARs around the announcements of takeovers. In contrast, both the BHAR and bidder's portfolio return approaches provide evidence of positive and significant long-term performance. Business cycle analysis shows that financial acquirers earn significantly higher returns during low-valuation markets compared to high-valuation markets. We also examine the ability of the market reaction around the acquisition announcement to predict bidder long-term performance and show that the market reaction to the bid announcement better predicts bidders' long-term performance in the case of positive short-term abnormal returns.

\section{AUTHOR INFORMATION}

Sabri Boubaker, Ph.D., is Associate Professor of Finance at Champagne School of Management (Groupe ESC Troyes en Champagne, France) and Research Fellow at the Institut de Recherche en Gestion (University of Paris Est). He holds a Ph.D. in Finance from University of Paris Est (2006) and a HDR degree (Habilitation for Supervising Doctoral Research) in 2010 from the same university. He was a visiting professor at IESEG School of Management (France) and IAE Paris Gustave Eiffel (France). He has recently published several academic papers in international refereed journals including Journal of Banking and Finance, Review of Accounting and Finance, Multinational Finance Journal, Global Finance Journal, International Journal of Business, and Journal of International Financial Markets, Institutions and Money. Dr. Boubaker has also edited several books on corporate governance and corporate social responsibility issues. He co-chaired the first Paris Financial Management Conference (PFMC-2013, Paris, France) and the 5th International Research Meeting in Business and Management (Irmbam-2014, Nice, France). E-mail: sabri.boubaker@groupe-esc-troyes.com (Corresponding author)

Taher Hamza, Ph.D., is Associate Professor of Finance and chair of the doctoral committee at Tunisia State University at Sousse. He is also Research Fellow at the VAL de LOire REcherche en Management (Vallorem University of Orléans, France). He holds a M. Phil from University of Jean Moulin (I.A.E.- Lyon III, France) in 1987, a Ph.D. in Finance from University of Grenoble II (Grenoble, France) in 1993 and a HDR degree (Habilitation for Supervising Doctoral Research) in 2009 from Tunisia State University at Tunis. Before joining the Tunisia State University, Professor Hamza has taught for more than 10 years in France at both Ecole Supérieure de Commerce of Clermont Ferrand and IAE Lyon III. His main research interests are corporate finance, corporate governance, and mergers and acquisitions. He published many academic papers in top French and international refereed journals. E-mail: taher.hamza@topnet.tn

\section{REFERENCES}

1. Agrawal, A., Jaffe, J. F., \& Mandelker, G. (1992). The post-merger performance of acquiring firms: A reexamination of an anomaly. The Journal of Finance, 47, 1605-1621.

2. Akhavein, J. D., Berger, A. N., \& Humphrey, D. B. (1997). The effects of megamerger on efficiency and prices: Evidence from a bank profit function. Review of Industrial Organization, 12, 95-139.

3. Amihud, Y., DeLong, G., \& Saunders, A. (2002). The effects of cross-border bank mergers on bank risk and value. Journal of International Money and Finance, 21, 857-877.

4. Andre, P., Kooli, M., \& L'Her, J. (2004). The long-run performance of mergers and acquisitions: Evidence from the Canadian stock market. Financial Management, 33, 27-43.

5. Binder, J. J. (1998). The event study methodology since 1969. Review of Quantitative Finance and Accounting, 11, 111-137.

6. Barber, B. M., \& Lyon, J. D. (1997). Detecting long run abnormal stock returns: The empirical power and specification of test statistics. Journal of Financial Economics, 43, 341-372.

7. Becher, D. A. (2000). The valuation effects of bank mergers. Journal of Corporate Finance, 6, 189-214.

8. Behr, A., \& Heid, F. (2011). The success of bank mergers revisited: An assessment based on matching strategy. Journal of Empirical Finance, 18, 117-135. 
9. Beitel, P., Schiereck, D., \& Wahrenburg, M. (2004). Explaining M\&A success in European banks. European Financial Management, 10, 109-139.

10. Berger, A. N., \& Mester, L. J. (2003). Explaining the dramatic changes in performance of US banks: Technological change, deregulation, and dynamic changes in competition. Journal of Financial Intermediation, 12, 57-95.

11. Bessler, P., \& Murtagh, J. P. (2002). The stock market reaction to cross-border acquisitions of financial services firms: An analysis of Canadian banks. Journal of International Financial Markets, Institutions and Money, 12, 419-440.

12. Bouwman, H. S., Fuller, K., \& Nain, A. (2007). Market valuation and acquisition quality: Empirical evidence. Review of Financial Studies, 22, 633-667.

13. Brown, S., \& Warner, J. (1985). Using daily stock returns: the case of event studies. Journal of Financial Economics, 14, 3-31.

14. Campa, J. M., \& Hernando, I. (2006). M\&As performance in the European financial industry. Journal of Banking \& Finance, 30, 3367-3392.

15. Chatterjee, R. A., \& Aw, M. S. B. (2004). The performance of UK firms acquiring large cross-border and domestic takeover targets. Applied Financial Economics, 14, 337-349.

16. Cuesta, R. A., \& Orea, L. (2002). Mergers and technical efficiency in Spanish savings banks: A stochastic distance function approach. Journal of Banking and Finance, 26, 2231-2247.

17. Cybo-Ottone, A., \& Murgia, M. (2000). Mergers and shareholder wealth in European banking. Journal of Banking and Finance, 24, 831-59.

18. Dimson, E., \& Marsh, P. (1986). Event study methodologies and the size effect: The case of UK press recommendations. Journal of Financial Economics, 17, 113-142.

19. Erickson, M., \& Wang, S. (1999). Earnings management by acquiring firms in stock for stock mergers. Journal of Accounting and Economics, 27, 149-176.

20. Franks, J., Harris, R. S., \& Titman, S. (1991). The post-merger share price performance of acquiring firms. Journal of Financial Economics, 29, 81-96.

21. Houston, J., James, C., \& Ryngaert, M. (2001). Where do merger gains come from? Bank mergers from the perspective of insiders and outsiders. Journal of Financial Economics, 60, 285-331.

22. Jensen, M. (1986). Agency costs of free cash flow, corporate finance, and takeovers. American Economic Review, 76, 323-329.

23. Loughran, T., \& Ritter, J. (1995). The new issues puzzle. The Journal of Finance, 50, 23-51.

24. Koetter, M. (2008). An assessment of bank merger success in Germany. German Economic Review, 9, 232264.

25. Malatesta, P. H., \& Thompson, R. (1985). Partially anticipated events: A model of stock price reactions with an application to corporate acquisitions. Journal of Financial Economics, 14, 237-250.

26. Manne, H. G. (1965). Mergers and the market for corporate control. Journal of Political Economy, 73, 110120 .

27. Mitchell, M., \& Stafford, E. (2000). Managerial decisions and long-term stock price performance. Journal of Business, 73, 287-320.

28. Olson, G. T., \& Pagano, M. S. (2005). A new application of sustainable growth: A multi-dimensional framework for evaluating the long run performance of bank mergers. Journal of Business Finance \& Accounting, 32, 1995-2036.

29. Pécherot-Petitt, B. S. (2000). La performance sur longue période des acquéreurs français. Banque \&Marchés, 46, 31-39.

30. Rhoder-Kropf, M., \& Viswanathan, S. (2004). Market valuation and mergers waves. The Journal of Finance, 59, 2685-7180.

31. Roll, R. (1986). The hubris hypothesis of corporate takeovers. Journal of Business, 59, $197-216$.

32. Shleifer, A., \& Vishny, R. (1989). Management entrenchment: The case of manager-specific investments. Journal of Financial Economics, 25, 123-139.

33. Shleifer, A., \& Vishny, R. (2003). Stock market driven acquisitions. Journal of Financial Economics, 70 , 295-311.

34. Williams, J., \& Liao, A. (2008). The search for value: Cross-border bank M\&A in emerging markets. Comparative Economic Studies, 50, 274-296. 